\title{
Editorial: Challenges and Innovative Solutions in River Sciences
}

\author{
T. Hein ${ }^{1,2 * t}$, D. M. Infante ${ }^{3 t}$, R. Schinegger ${ }^{1,4 t}$, J. Schoelynck ${ }^{5 t}$ and G. Weigelhofer ${ }^{1,2 t}$ \\ ${ }^{1}$ Institute of Hydrobiology and Aquatic Ecosystem Management, University of Natural Resources and Life Sciences, Vienna, \\ Austria, ${ }^{2}$ WasserCluster Lunz, Lunz am See, Austria, ${ }^{3}$ Department of Fisheries and Wildlife, Michigan State University, East \\ Lansing, MI, United States, ${ }^{4}$ Institute of Landscape Development, Recreation and Conservation Planning, University of Natural \\ Resources and Life Sciences, Vienna, Austria, ${ }^{5}$ University of Antwerp, Department of Biology, Ecosystem Management Research \\ Group, Wirijk, Belgium
}

Keywords: riverine ecosystems, biodiversity, new methodologies, management, stressors

\section{Editorial on the Research Topic}

\section{OPEN ACCESS}

Edited and reviewed by: Angela Helen Arthington, Griffith University, Australia

*Correspondence: T. Hein thomas.hein@boku.ac.at

tORCID:

T. Hein

0000-0002-7767-4607

D. Infante

0000-0003-1385-1587

R. Schinegger

0000-0001-9374-5551

J. Schoelynck

0000-0003-0166-280X

G. Weigelhofer

0000-0002-1298-2721

Specialty section:

This article was submitted to

Freshwater Science,

a section of the journal

Frontiers in Environmental Science

Received: 18 January 2021 Accepted: 12 February 2021

Published: 19 March 2021

Citation:

Hein $T$, Infante DM, Schinegger $R$, Schoelynck $J$ and Weigelhofer $G$ (2021) Editorial: Challenges and Innovative Solutions in River Sciences.

Front. Environ. Sci. 9:655473.

doi: 10.3389/fenvs.2021.655473
Challenges and Innovative Solutions in River Sciences

\section{INTRODUCTION}

The Anthropocence describes the time period when humans have become significant modifiers of the Earth's ecosystems (Waters et al., 2016), with dramatic consequences for riverine landscapes. Worldwide, rivers and their associated floodplains have undergone substantial transformations, leading to dramatic reductions of their integrity, natural multi-functionality and the diversity of ecosystem services they provide (Erös and Bányai, 2020). Parallel to this development, the complexity of social, economic, and ecological demands has increased, exercising multiple and often interlinked stressors on river-floodplain systems at different spatial and temporal scales (Birk et al., 2020). River managers have to perceive riverine landscapes as socio-ecological systems, in which human demands, attitudes and perceptions as well as ecological requirements must be collectively considered. This requires new approaches and innovative tools and solutions in river management to harmonize the ecosystem and human needs and to protect riverine landscapes from further degradation, while also considering their critical role for support of aquatic biodiversity (van Rees et al., 2020; Bonar, 2021).

This Research Topic presents selected original research articles from the sixth Biennial Symposium of the International Society for River Science hosted by the Institute of Hydrobiology and Aquatic Ecosystem Management at the University of Natural Resources and Life Sciences, Vienna (BOKU) Austria, from 8-13 September 2019. According to the conference theme "Riverine landscapes as coupled socio-ecological systems," the symposium emphasized integrative research on the sustainable use, management, and protection of riverine landscapes and societal implications (Weigelhofer et al., 2021). This special issue focuses on new insights in changes of ecosystem functions and biodiversity and approaches and tools leading to innovative solutions for river management presented at the conference which help to deal with current and future challenges in river research and management.

This special issue covers the following themes:

- Effects of changes to river ecosystems at landscape and global scales

- Innovative solutions to assess these changes

- Long-term strategic and integrative approaches in coupled socio-ecological systems 


\section{EFFECTS OF CHANGES TO RIVER ECOSYSTEMS AT LANDSCAPE AND GLOBAL SCALES}

Changes of human behavior and interventions at landscape and global scales have multiple consequences for riverine ecosystems, such as altered discharge, temperature and biogeochemical characteristics. Reduced hydrological connectivity of floodplains may impact the phosphorous buffering capacity of floodplain sediments, thus altering the total riverine phosphorous cycle (Preiner et al.). Furthermore, climate change affects aquatic organisms in multiple ways and may intensify prevailing human stressors. Salmonids of alpine rivers showed increased physiological stress and diseases (Borgwardt et al.), while macrophytes responded negatively to simulated climate induced changes of the interplay between flow velocity, DOC and $\mathrm{CO}_{2}$ (Reitsema et al.).

\section{INNOVATIVE SOLUTIONS TO ASSESS THESE CHANGES}

Addressing changes in river systems requires the continuous development of new concepts and tools to tackle specific- and multiple stressors, their altered patterns and effects on ecosystem services in these modified systems more accurately. The morphological structure of riverine landscapes has been largely altered, and human uses have changed them massively at least during the past 150 years, leading to a further change in interactions between humans and river systems (Haidvogl, 2018). Fisheries are a globally important, socially, ecologically and economic relevant ecosystem service. To study and manage social-ecological linkages occurring in salmonid fisheries, the metacoupling framework offers an innovative solution from the United States (Carlson et al.), by assessing and managing socioeconomic and environmental interactions within and between coupled human and natural systems at local, regional, and global scale. Secondary development of decoupled floodplains and conflicting policies present challenges to restoration planning of these systems. By combining single- and multiple-species approaches in an Austrian floodplain, Weigelhofer et al. provides insights into the potential of different restoration measures and trade-offs between different ecological aims. Likewise, a comparison of modeling approaches to estimate nutrient retention in decoupled and reconnected floodplain sections provides evidence of the strengths and weaknesses of the different approaches and the effects of potential restoration measures in Danube floodplains (Natho et al.). Regarding the management of nutrient dynamics, Teubner demonstrated that water transparency thresholds are a useful socioecological indicator for macrophyte and algal growth and hence recreational opportunities in an old, urban oxbow lake along the Austrian Danube.

Rivers transport enormous amounts of plastic debris, leading to massive accumulations in the sea (Lechner et al., 2014). This problem calls for new collection methods, as shown for Asian rivers (Owens and Kamil). Future changes in temperature regimes need new equipment to identify cold-water patches as critical refugia for endangered species, as shown by a combination of novel techniques (Casas-Mulet et al.). Invasive plant species are a significant global issue affecting riverine landscapes (Hofstra et al., 2020) and accurate measurements of tissue $\mathrm{H}_{2} \mathrm{O}_{2}$ concentrations provide a new approach to analyze stress intensity and identify stressors for plant growth as shown for Egeria densa in Japanese rivers (Asaeda et al.).

\section{LONG-TERM STRATEGIC- AND INTEGRATIVE APPROACHES IN COUPLED SOCIO-ECOLOGICAL SYSTEMS}

The critical situation of stressed and degraded river systems requires not only immediate actions, it also calls for long-term strategic and especially novel integrative approaches to address (river basin) management options at larger scales. Sievert et al. provided such an approach by considering established conservation networks in stream systems in Missouri, which can be an efficient tool to prioritize fish conservation sites throughout river networks. Further, interdisciplinary educational programmes can be a key element to face future challenges while supporting interdisciplinary and managementorientated science at an international scale, as shown for the SMART (Science for MAnagement of Rivers and their Tidal Systems) program (Serlet et al.).

\section{OUTLOOK}

These selected examples highlight current progress in freshwater conservation science and river basin management planning and emphasize that more efforts are needed to fully consider riverine landscapes as socio-ecological systems under the view of accelerated changes in the near future. In order to offer holistic solutions for these challenges, a new socio-ecologically driven research agenda is a promising approach. Thus, the following aspects need further attention to support new management schemes in riverine landscapes:

Considering riverine landscapes conceptually as socioecological systems would need the incorporation of socioecological concepts such as colonization of natural systems (Fischer-Kowalski and Erb, 2016) and social metabolism (Schmid, 2016) to address the coupling between ecological and societal systems. The integration of these concepts would allow to analyze the changing role of rivinere landscapes in the societal metabolism and the elements of the transformation of riverine landscapes.

There is a need to tackle problems and develop indicators more integratively to depict ecological and societal dimensions. New techniques, as for example in optical or acoustic imagery, and interdisciplinary approaches, as well as seeing rivers with their wetlands and surrounding landscape in a holistic way will support this. 
The complex setup of stressors acting on our river ecosystems calls for an intensified development of tool-sets, considering future drivers of change and related direct and indirect effects. This will support efforts to tackle conflicting goals of laws and directives and to diagnose more accurately consequences and more tailored management actions at appropriate scales.

More interdisciplinary doctoral programmes need to be developed to address the multi-dimensional nature of these coupled systems and educate a new generation of scientists facilitating the knowledge transfer to application.

Meetings that bring together inter- and transdisciplinary scientists and other actors from across the globe are a critical mechansim to develop strategies for conserving riverine landscapes as coupled socio-ecological systems; participation to jointly define key issues and novel solutions should be encouraged.

\section{AUTHOR CONTRIBUTIONS}

All authors listed have made a substantial, direct and intellectual contribution to the work, and approved it for publication.

\section{REFERENCES}

Birk, S., Chapman, D., Carvalho, L., Spears, B. M., Andersen, H. E., Argillier, C., et al. (2020). Impacts of multiple stressors on freshwater biota across spatial scales and ecosystems. Nat. Ecol. Evol. 4 (8), 1060-1068. doi:10.1038/s41559020-1216-4

Bonar, S. A. (2021). More than 100 aquatic-science societies sound climate alarm. Nature 589, 352. doi:10.1038/d41586-021-00107-x

Erős, T., and Bányai, Z. (2020). Sparing and sharing land for maintaining the multifunctionality of large floodplain rivers. Sci. Total Environ. 728, 138441. doi:10.1016/j.scitotenv.2020.138441

Fischer-Kowalski, M., and Erb, K.-H. (2016). "Core concepts and heuristics," in Social ecology: society-nature relations across time and space, humanenvironment interactions. Editors H. Haberl, M. Fischer-Kowalski, F. Krausmann, and V. Winiwarter (Cham, Switzerland: Springer International Publishing), 29-61.

Haidvogl, G. (2018). "Historic milestones of human river uses and ecological impacts," in Riverine ecosystem management. (Cham, Switzerland: Springer), $19-39$

Hofstra, D., Schoelynck, J., Ferrell, J., Coetzee, J., de Winton, M., Bickel, T. O., et al. (2020). On the move: new insights on the ecology and management of native and alien macrophytes. Aquat. Bot. 162, 103190. doi:10.1016/j.aquabot.2019. 103190

Lechner, A., Keckeis, H., Lumesberger-Loisl, F., Zens, B., Krusch, R., Tritthart, M., et al. (2014). The Danube so colourful: a potpourri of plastic litter outnumbers fish larvae in Europe's second largest river. Environ. Pollut. 188, 177-181. doi:10.1016/j.envpol.2014.02.006

\section{FUNDING}

Sponsorship and financial support was provided by: Amt der Niederösterreichischen Landesregierung-Abteilung Wissenschaft und Forschung no. K3-F-328/003-2018; via donau-Österreichische Wasserstraßen-Gesellschaft $\mathrm{mbH}$; Austrian Joint Water Initiative; Verbund AG; International Association for Danube Research (IAD and OEK-IAD); City of Vienna, MA45-Wiener Gewässer; ATS-Advanced Telemetry Systems. TH was supported by Austrian Science Fund (FWF), project FLASHMOB, no. I3216-N29.

\section{ACKNOWLEDGMENTS}

The 6th Biennial Symposium of the International Society for River Science (ISRS) was hosted by the University of Natural Resources and Life Sciences, Vienna (BOKU), in cooperation with the International Association for Danube Research (IAD), the I.S. Rivers conference (Integrative sciences and sustainable development of rivers) and the International Conference on the Status and Future of the World's Large Rivers. We thank all the authors and reviewers who contributed their time to this special issue.

Schmid, M. (2016). "Long-term risks of colonization: the bavarian 'donaumoos', in Social ecology: society-nature relations across time and space, humanenvironment interactions. Editors H. Haberl, M. Fischer-Kowalski, F. Krausmann, and V. Winiwarter (Cham, Switzerland: Springer International Publishing), 391-415.

van Rees, C. B., Waylen, K. A., Schmidt-Kloiber, A., Thackeray, S. J., Kalinkat, G., Martens, K., et al. (2020). Safeguarding freshwater life beyond 2020: recommendations for the new global biodiversity framework from the European experience. Conserv. Lett. 14, e12771. doi:10.1111/conl.12771

Waters, C. N., Zalasiewicz, J., Summerhayes, C., Barnosky, A. D., Poirier, C., Gałuszka, A., et al. (2016). The Anthropocene is functionally and stratigraphically distinct from the Holocene. Science 351 (6269), aad2622. doi:10.1126/science.aad2622

Weigelhofer, G., Brauns, M., Gilvear, D., Haidvogl, G., and Hein, T. (2021). Riverine landscapes: challenges and future trends in research and management. River Res. Appl. 37, 119. doi:10.1002/rra.3769

Conflict of Interest: The authors declare that the research was conducted in the absence of any commercial or financial relationships that could be construed as a potential conflict of interest.

Copyright (c) 2021 Hein, Infante, Schinegger, Schoelynck and Weigelhofer. This is an open-access article distributed under the terms of the Creative Commons Attribution License (CC BY). The use, distribution or reproduction in other forums is permitted, provided the original author(s) and the copyright owner(s) are credited and that the original publication in this journal is cited, in accordance with accepted academic practice. No use, distribution or reproduction is permitted which does not comply with these terms. 